\title{
Million Dollar Baby
}

\author{
By John Izod
}

Fall 2005 Issue of KINEMA

\section{MILLION DOLLAR BABY: BOXING GRIEF}

AS Ed Buscombe remarks in his review of Million Dollar Baby (USA, 2004) it, like most movies that feature boxing, does not make fighting its principal subject, but deploys it as a metaphor for life (2005: 67-8). In this sub-genre, themes such as courage, loyalty, comradeship, endurance, betrayal, blind anger and one form or another of corrupt behaviour (both in and out of the ring) commonly occur. At various times the main protagonists in Million Dollar Baby show most of the virtues and vices just listed. They provide, so to speak, the basic topography against which Million Dollar Baby is plotted. The film is distinctive, however, because while these moral issues are constantly in the background, it foregrounds two less familiar themes - firstly, the strange, counter-instinctive skills that the boxer must learn; and secondly, the repression and displacement of grief together with the necessity eventually to confront that pain.

In Million Dollar Baby, the boxing world is grubby and, for all but the stars, impoverished. The Hit Pit Gym owned by Frankie Dunn (Clint Eastwood) looks so run-down it bears out his remarks that nobody ever made money from operating a gym. The gym scenes' drab colours and dull, relatively low-key lighting match the short sequences in Frankie's house. This is the more striking in that the bright exterior of the property is not distinguishable from others in the sun-washed streets of this tree-lined Los Angeles suburb. Seen from outside, it fits well with the whitewashed neighbourhood church where he attends Mass each day, quite different from the grubby industrial wasteland into which the gym is squeezed. Yet the interior of his house, far from being a welcoming home, has the bare functionality of an unloved bachelor pad to which its owner retreats only to sleep. Its drab, brown rooms signal the dulled state of its owner's psyche. Frankie drives a battered, dying car and could never have afforded a property in this smart middle-class street; so it is open to conjecture that it may have come to him through a failed marriage.

A figure even more impoverished than him is his caretaker, Eddie Scrap-Iron Dupris (Morgan Freeman) who ekes out an existence only one step from Poverty Row. Living in a box room at the gym and seemingly dependent on his boss for handouts, his one luxury is the pay TV service on which he watches fights. Scrap's socks have holes in them - because, he says, he prefers not to take money Frankie offers him lest he gamble it away. That could be true, or a sardonic invention to save Frankie's face; yet this is not an exploitative relationship. Each man depends heavily on the other and there are strong bonds between them. Wary friendship and mutual loyalty link them.

As Frankie's good but under appreciated shadow, Scrap is not only a protagonist, but also the film's narrator and back-street philosopher. In this respect he resembles Red, the character whom Freeman played in The Shawshank Redemption. Although no older than Frankie except in the burden of self-knowledge, he functions as both the trainer's and the audience's wise old man. The sorry condition of Scrap's socks punningly implies his access to the $[\mathrm{w}]$ hole. In this respect he differs from Frankie who would never stoop to "holy" footwear - rather, he looks for the holy in church. Scrap talks about the nature of boxing as seen not by punters in the ringside seats but by the pugilists. It is a craft whose techniques demand so much in labour, energy and focus from trainees and trainers alike that it overwhelms every other preoccupation. The boxer must have heart, but that's far from the most important quality. The gym sports a sad example in Danger, a hapless street kid whose heart bursts with desire to escape nonentity and be a champion. But lacking both technical skills and the focus to acquire them, he is a danger to himself rather than others whenever he steps into the ring. He never gains in competence and is brutally hurt by the gym bully in a one-sided knock down to which Danger willingly if stupidly submits. This gangly youngster's naïve attraction to danger represents the compulsive need of someone who has been exposed to it in his earlier life. We shall discover that in this he and Frankie stand at opposite ends of a spectrum: the older man avoids risk, the younger recklessly hurls himself at it. Yet at the end of the story, Danger returns to the gym. It's an indication that to grow, people have to have danger in their lives, but it must be competently managed.

Danger cannot master the phenomenon that Scrap describes as the way everything goes backwards in the 
sport. Boxers, the older man says, have to be trained by endless repetition to act in patterns that run counter to what instinct tells them. Where instinct says go left, boxers must learn to go right. They push themselves beyond endurance, risking everything for a dream that nobody but them sees. The camera dwells on the wearying practice of these routines - whether they occupy the foreground or grind on in the background while the main protagonists are focusing on other matters.

As Laplanche and Pontalis remark in a passage which could have described the sport -

At the level of concrete psychopathology, the compulsion to repeat is an ungovernable process originating in the unconscious. As a result of its action, the subject deliberately places himself in distressing situations, thereby repeating an old experience, but he does not recall this prototype; on the contrary, he has the strong impression that the situation is fully determined by the circumstances of the moment. (Laplanche and Pontalis, 1973: 78)

The idea of doing things backwards contains the kernel of a metaphor with a long reach. The early Greek imagination envisaged the past and the present as in front of us, which explains how we can see them. The future, however, is invisible and therefore behind us. Only a few wise men can see what is behind them; some of these, like the blind prophet Tiresias, have been given this privilege by the gods. The rest of us, though we have our eyes, are walking blindly backwards into the future (Knox, 1995). Sure enough, the half-blind Scrap is the only man who can foresee the future in Million Dollar Baby, the only man who is not walking backwards into his fate.

Frankie Dunn, unlike the usual battle-hardened trainers in most boxing movies, is (within tight limits of his own imposing) not an unreflective man. Yet the business of training in which he is involved quells in him no less than his fighters any emotion that cannot directly be used in the ring. This discipline serves particularly well in the repression of feelings of loss since every boxer (so Scrap's mantra goes) can lose one fight. It's just that he must then work all the harder and with even more steely determination in order to return and triumph in the ring.

Frankie attends Mass every day, partly, it seems, so that he can torment the priest with obdurate questions about the nature and mystery of the holy trinity. This sparring contest has been going on for a long time between Frankie (playing the blockhead he patently isn't) and the clergyman. Exasperated that Catholic doctrine should be so blatantly challenged, Father Horvak (Brian F. O'Byrne) briefly rids himself of his scourge by telling Frankie to stay away from Mass for a day or two, pray and write to his daughter, Katie. Frankie receives this instruction with a touch of insolence which hints that he is lying to the priest in claiming to write every week. It turns out much later that this has been a fine piece of acting by Frankie to hide the truth that he cannot bear to contemplate. This makes it also, of course, a particularly subtle moment in an extraordinarily compact and understated performance by Eastwood himself. It is quite late in the film when we discover that Frankie does indeed mail his daughter regularly. The letters have for years been returned unopened, yet he continues trying to reach her. So he knows where she lives, but she refuses any contact with him. Frankie's heartache over the loss of Katie is the first key to an aspect of his personality that he tries hard to conceal. But repetition, when neurotically obsessive, becomes as addictive as danger and keeps a person locked in the past. This has occurred with Frankie repeatedly attempting to get in touch with the feminine which constantly rejects him.

Although his pain is so deep that he has gone to the priest, he cannot, as a man locked into a man's world, admit his weakness. He taunts the clergyman to hide his feelings. His jibes, centring on core doctrinal teachings of the Catholic Church, at first hearing suggest that Frankie must be confronting an issue of faith. But the priest is not fooled. He realises that Frankie, coming to Mass every day for 23 years, has been seeking help, not to find a spiritual home but because, unable to hold his own suffering, Frankie makes the church its container.

Bereavement counsellors Geraldine M. Humphrey and David G. Zimpfer could have had Frankie in mind when they observe that loss is not only an integral part of life but that losses accumulate as an individual goes through the transitions that the years bring (1996: 1). In addition to his missing daughter, Frankie's woman has been gone so long that she is never mentioned by Scrap and only fleetingly in Frankie's bedtime prayer, "Lord, protect Katie. Annie too." And these two missing members of his family by no means account 
for all his losses. Frankie dreads allowing the people with whom he is concerned to face their own challenges. The mantra he drills into his boxers has become a part of the psychology that governs his own life: "The rule is to protect yourself at all times." But when he protects people, he inhibits them from the potential of maturing into the full dignity of their selves. What is eventually revealed to be a pattern is first seen when he holds back a boxer whom he has been training for a long time, an excellent prospect for major success. Big Willie (Mike Colter) has reached the peak of his ability and is ready for a title fight. But Frankie insists on an endless series of preliminary bouts with unimpressive opponents. Reluctantly Willie leaves his camp for a manager who secures the world title fight swiftly - at which the big man triumphs. Willie has recognised Frankie's limitation; but in prioritising loyalty to himself has inflicted another loss on the trainer. As it happens the injury this causes will be of advantage to the latter in helping him move forward eventually, though not until after his next protégée gets into difficulty through Frankie's inhibition.

Not until much later does Scrap reveal the source of Frankie's obsessive need to control and protect his fighters. It stems from a loss 23 years earlier when Scrap himself was the man in the ring. Hired as his second for that night only, Frankie had wanted to throw in the towel because his man had already been badly hurt. However, only a manager could do this, and Scrap's manager was in a bar getting drunk. Scrap insisted he could turn the fight around and continued when the bell rang, a ruinous decision that cost him an eye and Frankie his peace of mind. Ever since, Frankie has employed and housed Scrap in the gym, unable to forgive himself (in a false fantasy of omnipotence) for an injury he had no means of preventing.

As Humphrey and Zimpfer show, the grieving process necessary after any major loss matters because, once lived through fully, it enables an individual to move forward into renewed life. Unfortunately British and North American social conventions have shaped the culture so evident in Million Dollar Baby where grief is legitimated only by death. This inhibits grieving for the many other kinds of loss - phenomena as diverse as separation and divorce, change of home, theft of precious possessions and the physical and mental changes that come with ageing. Here, in stark outline, is Frankie's predicament. It is always with him because, as Humphrey and Zimpfer insist, the grieving that follows loss cannot be the passive process many perceive it to be. It is not an affliction to get over as one gets over an unpleasant illness such as mumps or measles which cure in their own time. On the contrary, grieving must be undergone, with the pain suffered (or avoided in the way Frankie tries) and the whole process being understood. The full recognition of loss must then be incorporated in the individual's life in order to permit adaptation to his or her changed circumstances (Ibid: $1-2)$.

Losses are multiple in the sense that the experience of each loss is influenced by the previous ones which the individual has suffered (Ibid: 1-2). Frankie has suffered losses that are linked and has not found a way to mourn them, adapt and move on. Despite the crippling impact on both his professional and personal life of what has been taken from him, he has found no means of adapting his expectations to meet the continuing emotional cost. By contrast, Scrap (who has taken responsibility for his own decision) has long ago worked through grieving for the loss of an eye and has adjusted to his injury in a way that Frankie never could.

The oppressive refusal to allow the people he cares for to take risks in the process of growing into full selfhood may have destroyed any relationship Frankie once had with his woman. It may well also have been the underlying cause of the rift from his daughter. Frankie imposes too much Law for anyone who wants to become his or her own person to live indefinitely within his orbit. The only exception is Scrap, who has become wise through suffering serious injury himself and learning the healing power of acceptance. He alone among the male characters perceives that Frankie's insistence on the rule of his law is driven ultimately by a need which the trainer himself cannot recognise. Yet it comes out in the inflexible rule that he drills into all his fighters: "The rule is to protect yourself at all times." This is the rule by which Frankie himself lives - the law that permeates both his conscious and unconscious behaviour. Significantly, self-protection is one of the fundamental psychological themes that surface repeatedly in counselling and keeping the barriers up - always protecting the self - is hard work. Defending against the bad also locks out the good. Frankie will have to learn how to relinquish his insistence on protecting himself if, like anyone else who is frozen in pain, he is to adapt to the changes that circumstances impose on his life. Grief that is not lived through inhibits development of the self.

There is an absolute absence of the feminine in the tacky Hit Pit Gym until, determined to become a 
professional boxer, a youngish woman pushes her way in. No wives, girlfriends, or female trainees come through its doors, though other gyms do train women. Nor does any touch of Eros soften the pervasive Logos. Paradoxically, the dominance of Frankie's autocratic and masculine law may be a factor that actually attracts Maggie Fitzgerald(Hilary Swank), given that her circumstances mirror his. After her beloved father had sickened and died, her family had lost such balance as he had been able to maintain. No longer contained by the father, the others' dependency erupted and turned it into a hell-hole ruled by two monstrous and mean-minded women, her mother and sister. Usually a child primarily identifies with its same-sex parent and needs to be validated by the opposite-sex parent. Maggie, however, has identified with her father, the only healthy choice available to her. She can be compared with her sister who identified with their mother. There is no spark of kindness in either the sister or mother, and their home offers Maggie no loving female exemplar on which to model herself. Their most pronounced quality is greed (the mother is grossly overweight). Narcissistic behaviour appropriate in a baby's appetite for its mother's milk, is pathological in adults. Indeed, the mother and sister are so undeveloped that psychologically they are babies. As Laplanche and Pontalis say, this primitive state, called primary narcissism is characterised by the total absence of any relationship to the outside world, and by a lack of differentiation between ego and id (1973: 256).

The only thing Maggie has been taught by the women in her family is that she is trash. Rather than sink into the mire, however, she uses grief for her dead father to create something new. Given her family history, it is no surprise that she wants to stay attached to a paternal figure. She is a father's daughter, something that makes her feel special. In her life only Logos has been shown to be dependable and professional boxing is her chosen way into that world. Therefore Maggie has made an emotional investment in being different. Loathing the cheating way her mother and sister live on bogus welfare claims and disgusted by dependency, Maggie waits on table in cafes and diners, eking out an existence on the margins. But after moving to LA from their trailer park in the Ozarks, she finds finances desperately hard. Reduced to eating leftovers from customers' plates and dossing in the meanest rooms, she scrapes together the cash needed for training. Paying fees months in advance gains her entry to the gym; but Frankie refuses point blank (time and again as the weeks pass) to have any part in training her. Symbolically he is rejecting the very feminine that he so much needs. Nevertheless, despite being brusquely dismissed by him - she is too old at thirty one... she has no hope of making it... she should go to one of the gyms nearby which do train "girlies" - Maggie is undeterred. Since no rational explanation is offered for her choosing Frankie in the first place, nor for her persistence in the face of painful rebuffs, it is evident that an overwhelming intuition has led her to him.

Her persistence first wins Scrap's sympathetic collusion. He offers her a few training hints and by giving her minimal equipment and a thread of hope enables her to begin to wear Frankie down. Here we see an early indication that Scrap is a true, though wounded healer, fashioned after the type of the Ancient Greek Asklepios. By helping Maggie resist Frankie's attempts to eject her from the gym, he begins to reintroduce the feminine to the masculine. Scrap is the container of a wisdom (wisdom in the stink of the gym) that Frankie (who actively resists whatever advice the caretaker offers him) has yet to find for himself.

Eventually, however, Frankie's resistance is broken by the desperate need that underlies Maggie's dream of boxing glory. By aggressively refusing to give up her dream she demonstrates masculine characteristics. When she shows him that this is the only way she can give her existence meaning, he concedes gruffly. Not that he abandons his personal armour. While reluctantly agreeing to take her on, he dictates a rigid set of conditions - in effect a one-sided, self-protective contract. She must do exactly what he tells her. She must not question anything he says. Furthermore, when he has trained her fully, she will have to find a manager for herself and then he will have no further contact with her. As usual, Frankie retains the Law firmly in his own hands and is repeating the pattern of exerting control to ward against loss. Sure enough, when eventually against all the odds Maggie does attain fight fitness, Frankie holds her back from major contests. In the meantime, however, she accepts his terms and devotes herself wholeheartedly to working up her craft. There is wisdom in the feminine: she knows what she needs.

A remark by Frankie hints at an unconscious readiness for change that he certainly would not have been able to admit to himself. He mutters that he probably keeps the gym going only because he loves the stink. In the context of Frankie's inner life, we can take this aside as a suggestion that his unconscious may be ready to ferment growth: our psychological life resides in the stink of the unconscious. 
Maggie is a driven woman, and although Frankie's instructions amount to an attempt to control her, she has heart in plenty. In time personal feelings inevitably insinuate themselves into their professional relationship, however much Frankie resists them. For example, he cannot but admire the ferocious purity of her focus; and she in turn begins to flourish, nurtured by the sense of value gained from Frankie's minute attention to her training regimen. Their relationship deepens as the weeks pass and each gets glimpses behind the tough mask of the other. Frankie speaks briefly about the daughter with whom he no longer has any connection and mutters that Katie used to be athletic. Not hard to see that Maggie is the only person who could fill the hole in his heart; but it's not a role that she could claim in any overt way because his defences are too massively buttressed. So Maggie toils away as Frankie's trainee, observing the terms he lays down; but in fulfilling them she also gradually slips into the role of daughter. Her wry sense of humour begins to subvert the emotional detachment that he wishes to impose on the relationship through his dictatorial terms. However, wisecracks alone would never suffice to melt Frankie. It takes her combination of subaltern wit, toughness and aching need to begin to crack open his crusty facade. Neither of them could put this into words, and if someone like Scrap had spoken in these terms, they would have repudiated them. Nevertheless, Maggie in effect "trains" Frankie's heart. She thaws his frozen grief just as he repairs her sorrow. Each becomes the other's family. The tortuous process through which they open each other out is the equivalent in their relationship of the boxer having to do everything backwards. And the development of feelings between them not only tests her strength but also starts to wear away his depression. Maggie eventually restores Eros to both Frankie's and her own life, introducing a sense of aliveness where depression had brought an emotional deadening.

Not that Frankie initially has any claim on her other than as trainer. And he gives up even that right (as he said he would) when he refuses to arrange a fight for her and pushes her toward a manager. However, for his own financial gain, that unscrupulous manager puts her in the ring with an opponent too strong for her. Maggie gets into serious difficulties. Goaded by Scrap, who sees that his old friend has betrayed his fighter by abandoning her, Frankie forces his way to ringside and takes command of the bout. His curt directions remedy Maggie's technique and sting her into the ruthlessness needed to redeem the bout. This is the first instance of the synergy of masculine and feminine arising from his responsiveness.

The episode marks the moment when Frankie begins to wrest a hard-won accommodation to the past traumas that have crippled his work and life. Loss is an event which "requires that some part of the individual be left behind and grieved before the process of transition and rebuilding can occur" (Humphrey and Zimpfer: 1996: 1). Frankie has not only redeemed his betrayal of Maggie but also intuitively taken the first step toward recovery from the old losses in accepting the responsibility to manage her. In so doing he manages also his own grief rather than splitting it off. It is the first indication of his willingness (without being able to verbalise it) to change the ways to which he has become conditioned. Since the grieving process is a cycle that has to be worked through time and again, it is reasonable to anticipate that Frankie will have to experience more pain before the process is done (Ibid.). Nevertheless, the near disaster of that first major fight delivers more than a professional turning point for both Frankie and Maggie and marks the start of a mutually trusting personal relationship.

Frankie Dunn is no dullard. But nothing in what the audience has discovered about him prepares it for the incongruous use of his spare moments in the gym. Although he does not care to reveal it to anyone other than Scrap, he is teaching himself Gaelic and relishes the poetry of W.B. Yeats. He never explains why, but exercises his mind with repetitions that seem as tough and counter-intuitive in their own way as the boxers' physical routines. But here, rather than reinforce the old mental conditioning, he is developing new ways of thinking. Eastwood may well from the director's chair have had in mind doffing his cap to John Ford and John Huston. Both were Irish-American filmmakers with a well-known love of boxing and the old country. Certainly, Million Dollar Baby can be seen as an homage to Huston's Fat City, an equally keen evocation of the sport as a seedy business (French, 2005). But how do the literary interests of the character Eastwood plays fit his role? Frankie shows no ambition to visit the old country and perhaps has no more than a nostalgic passion for the ancestral home, in common with so many Irish Americans. So we cannot for a long time understand the resonances the language and poetry has for him.

In the meantime, buoyed by the knowledge and confidence she receives from him, Maggie seems suddenly to have become unstoppable. Now the synergistic affect of the masculine working in conjunction with the 
feminine makes itself felt constantly. Eastwood allows the audience to enjoy her successes as they mount up rapidly - her fans growing in noisy number, her opponents knocked over in the first round and her promotion to an altogether tougher league. Soon, partly from an unsuspected delight in showmanship and also to give Maggie her due, Frankie gives her a new name and the glamorous apparel of a championship contender. He has "Mo Cuishla" embroidered on emerald shorts and her silk dressing gown, but declines to reveal its meaning before she becomes world champion. Rather than the blare of triumphant pop music that accompanies her opponents' parade to the ring, pipers escort Maggie's entry. She thrills to the panoply even though (like most of the audience) she has no idea what her new name, heraldic for Frankie, should mean to her.

As soon as she is earning good money, Maggie buys a house for her mother (Margo Martindale) so that she and Maggie's sister can move out of the trailer park. After winning a fight not too far from their home, she persuades Frankie to make a detour to surprise the women with the gift. But her mother, a woman so gross she must have stuffed fast foods for decades, can only berate her daughter for the gift because she realises that owning a house will put at risk her ill-gotten welfare benefits. The sister, another welfare cheat, is so mean-spirited that she can only find fault with the new dwelling. And the mother repays Maggie's kindness by scorning her choice of sport as freakish. Maggie's unconscious attempt to heal her own wounded feminine has been a complete failure because she focused on the actual mother. In mid-life, it is critical to focus on the internal image of those who have been formative in personal development, rather than on their actual present counterparts. Maggie's actual mother has no interest in changing - as symbolised by her stuffing food whose lack of nutritional value signifies her own vast emptiness. It is Maggie who is working toward changing.

Back on the road, as they drive through the night, Maggie allows sorrow to well up. While their faces slide in and out of darkness to visibility under passing streetlights, she tells Frankie that she has nobody but him. The experience has pushed her out of denial and into healthy grieving, recognising that she has been alone since her father died. Her words touch him deeply because of his similar loss and he tells her that she has him. As Roger Ebert noticed, "the rhythm of this lighting matches the tone and pacing of the words, as if the visuals are caressing the conversation" (2005). Like Tom Stern's chiaroscuro cinematography throughout, it complements the oscillating process of moving between darkness and light as they share their sense of loss of family. Maggie gives voice to emotional recollections of the father she loved and Frankie's gruff response speaks volumes about his empathy. The visit has been the second, necessary dramatic disaster Maggie and Frankie have shared. Whereas previously both father and daughter pairs were like different parts of the psyche that were not yet integrated (see Samuels, 1985: 30), this visit helps bond them as a new family and this time they both know it. Here are the beginnings of the new "spiritual family", a new wholeness.

Now Maggie gives Frankie directions (reversing their roles in the first disaster) and guides him to Ira's diner, where her father used to drive to enjoy the best homemade lemon pie in the world. The pursuit of perfection in this dish happens also to be Frankie's only sensual Grail - one of the few passions to which he can admit. At the risk of over-egging the pudding, notice that the lemon pie can be interpreted as soul - eating it is a metaphor for the process of recovering from grief. The bitterness has to be tasted, but after it, sweetness prevails. Having eaten, Frankie announces that he can now die and go to heaven. It is a quiet moment, but a celebration nonetheless.

Frankie now negotiates fifty percent of a one million dollar purse for a title fight - the pinnacle of Maggie's career. However, the current champion does not wear the belt for her unaided pugilistic skills alone, but because she will do anything to win. She cold-bloodedly sets out to destroy Maggie with foul punches another indication of the wounded feminine. Frankie, who has never done so before, orders his girl to use her only defence and respond in kind. Having weakened the champion with a succession of blows to the kidneys, Maggie floors her. In the bedlam that follows, our hero is already celebrating when the hired man acting as her second (Scrap having declined to join the team) puts the stool into the ring prematurely and on its side (mistakes which Frankie never makes). The downed champion rises from the canvas and takes a vicious swing at her opponent who has turned away to share success with her fans. The blow knocks Maggie over and her neck breaks over a leg of the stool.

Several people bear responsibility for the injury that leaves Maggie a paraplegic dependent on machinery for 
every breath. The champion, Frankie and Maggie herself head the list for breaking the sport's laws. Scrap (for staying away) and the hired second for his ineptitude also share in the blame. However, Scrap in his narration shows no interest in attributing blame. Indeed, a dispassionate look at what passed in the ring reveals that, in addition to rule-breaking and incompetence, happenstance played a part in maiming Maggie. She also forgot to "protect herself" after knocking down her opponent - a failure she admits to her trainer after recovering consciousness. However, had the bout been conducted according to the rules, she would have had no need to do so at that moment because the referee had already stopped the contest. When the rules of sport are abandoned, something akin to warfare breaks out. Frankie's decision to break the rules is an indication he has allowed himself to move beyond the rigid psychological position of rules and laws toward a fuller personal integrity. In psychological terms, in the immediacy of the crisis, Frankie has moved to save the feminine, his anima. His violation of the rules is driven by an appropriate regression from socially accepted mores to honour the stronger need to save Maggie - a moment which represents an awakening of his soul. The contestants in this bout have gone backwards to an elemental atavism in the attempt to gain victory. In psychoanalytical terms that implies transcendence, a topic to which we must return.

There is a curious obliquity in the presentation of the fight's ending since the spectator is left uncertain until much later whether Maggie has been judged to have won or lost. The point is that the championship no longer matters to either her or Frankie. They have other, more important concerns. That the protagonists have entered a new psychological as well as dramaturgical realm is signalled by the bloodless blue of the hospital sequences. Frankie initially responds to the maiming of his girl with rage that verges on hysteria. He tries to load his guilt into Scrap, transparently seeking to relieve his own sense of culpability. Then he directs his anger at Maggie's doctors, insisting their diagnosis that nothing can be done for her is wrong. This is classic behaviour on the part of grieving family members and shows their inability to hold the suffering. Faced with bad news about someone they love, they often experience anger directed at medical staff, a denial that may take the form of shopping around for different opinions, as Frankie does (Kübler-Ross, 1969: 149). In his shock he projects the complete failure of his own omnipotency onto the doctors. This is all the evidence we need that by repeating and intensifying what had previously happened to Scrap, Maggie's injury threatens to immure Frankie once again in the emotional ice from which he has only lately emerged. It is a time fraught for him with the risk of regressing and losing all that he had gained.

It is Maggie who once again saves Frankie from himself. She never complains about what has happened. Nor does she lose her fighting spirit or her sense of justice. Both animate what turn out to be her final dealings with her birth family. Despite Frankie's many phone calls, the rag-tag brigade shows no interest in visiting her, and the weeks pass. Eventually, after Maggie has been brought by ambulance back to LA, they do make the journey from the Ozarks. But having checked into a hotel, they devote their time to amusing themselves in Southern California's theme parks, re-emphasising their childishness. When finally they do call at the hospital, they bring along a lawyer and it soon becomes plain that their only interest is in persuading the incapacitated young woman to sign her money over to them. Frankie's outrage is almost beyond containment, but Maggie insists on dealing with the family without his support. She commands full authority and no longer needs him to protect her because she now contains the internal resources to deal with them. His reluctant acknowledgement of her demand marks new trust of the feminine.

Indifferent to the injury that has left Maggie unable to move her limbs, the family wheedle for her cash. Showing no compunction, her hideous mother clumsily slots a pen between Maggie's teeth and urges her to sign the legal papers. Her relatives' narcissistic dependency on her is complete, but Maggie now knows that she no longer responsible for parenting them. Fired to cold anger, she dispatches them with the one threat she knows will hit hard. Her mother having failed to sign the deeds for the house (because she would have had to give up her illegal welfare claims), the property still belongs to Maggie. She tells the family that she will sell it if they ever pester her again. As Scrap says, commenting on an earlier incident, Maggie always did like to knock out her opponents in the first round.

Thus where it remains within her power, Maggie focuses her anger purposefully, without trying to remedy the irreparable. Far from being consumed by regret, she celebrates having been up there with the greats, telling Frankie that with her success and the enthusiasm of her fans "I got it all - unless they keep taking it away from me." Her anger is directed not at the past but against a future in which, as her body deteriorates and she loses a leg to gangrene, she can see how, blow by surgical blow, her vitality will be leached from her. 
She determines to refuse a half-life that negates everything she has achieved: the prospect of being cooped in her own rotting carcass sustained indefinitely by a respiratory machine is for Maggie a horror worse than death.

No human experience is more apt to induce narcissism than an individual's personal pain and suffering. This is obvious when comparing Maggie with her odious family. She is far from narcissistic, harbouring neither self-pity nor anger, focused instead on moving forward. Whereas in the past she, like Frankie, has had to grieve for a broken attachment, now she must seek non-attachment in order to achieve transcendence. Kübler-Ross wrote (in a passage which could have described Maggie's achievement) that the process of dying, all the suffering, allows the patient who learns to accept it to temper the iron and gives her the opportunity to grow (1995: 35). In this process, a secure personal attachment allows sufficient space for each party to be what he or she is and to let go when the need arises. Maggie actually embraces a final opportunity for growth by seeking to bring on her own death in the face of inevitable physical decline. She no longer needs the body to individuate but can do so by surrendering to experience.

A parallel process of growth can be achieved by someone who loves a dying person. The more that preparatory grieving can be expressed beforehand, the less unbearable the death when it occurs (Kübler-Ross, 1969: 14950). Frankie does not know this beforehand but arguably finds it out after giving Maggie the terrible help she asks for. Psychological preparation creates a larger container to bear the eventual suffering. Having said this, his easement does not come without extreme pain.

Maggie asks him to make the supreme sacrifice - to release her from living death. He is unable at first to let her go. Such is the extremity of her soul, however, that after he denies her she attempts suicide by biting off her tongue (doing it again after the medics stitch it back on). Her act has monstrous, even outrageous qualities, but makes her the wounded healer of herself. Commands proceed from the tongue, so her violent act mutely communicates to Frankie that if he won't respond to her, she has nothing more to say to him. She as the feminine, the soul, retains complete control.

Thus she confronts Frankie with a dreadful predicament, all the more conflicted by the bond that ties him as loving father to his maimed daughter. Not only is Maggie's body still dying by inches, but the nursing staff have injected a strong sedative, thereby robbing her of control. They mean to prevent her trying suicide again; but by succumbing to the moral and legal pressures to which all medical staff are exposed and attempting to preserve life at all costs, they have expunged the freedom of her soul. The moral and spiritual agony that her suffering causes in Frankie drive him back to Father Horvak. The priest advises him, "If you do this thing, you'll be lost somewhere so deep you will never find yourself." This edict is a key indicator of his limitations and explains why he has never been able to help the trainer. He is a man of the Church and as such is not open to change. In fact, his relationship to Frankie can be compared with Mrs Fitzgerald's to her daughter. Neither "parent" is interested in change. Both are afraid of depth and what lives within that depth. Although Father Horvak has Frankie's interests at heart, he turns out to be mistaken and is not a soul-directed man.

Maggie's desperate attempt at annihilation and the guidance that Scrap offers persuade Frankie. The wise old man tells the trainer that Maggie is ready for death, having achieved her life's ambition, something more than most people do. It is what the other man needs. He returns to Maggie's hospital room in the dead of night with his medical kit. Only now does he tell her that her Gaelic nom de guerre Mo Cuishla means "My darling, my blood". These words anoint Maggie with the ritual blessings of a rite of passage. They show that he has earned the right of parenthood to his daughter. No sooner has he given her his blessing than he performs the ultimate act of love with the supreme sacrifice and administers a massive overdose of adrenalin to end the existence of his beloved child.

The focus of the story now shifts to Scrap who has followed Frankie to the hospital, secretly observing his final moments with Maggie. It turns out that Scrap has been motivated by the trainer's courage to tell the story to Frankie's long-lost daughter Katie. By tenderly explaining her father to her, Scrap once again brings the masculine to the feminine and attempts to make things whole.

Scrap concludes his account by reporting that Frankie never returned to the gym and all-male experience. The consequences of what in extremis he did to end Maggie's life have forced him to flee. Now a fugitive 
from the law (an intriguing reversal of roles for the old Law giver), moving on has brought to an end the longest phase of his life. The boxing milieu and everything which that framed for him has been left behind. Taken together with the pain of Maggie's, the transformation of his existence amounts to a kind of death. Yet there is regenerative compensation for his loss. When Scrap brings his account to an end, he allows us to conjecture that Frankie may have returned to Ira's country diner. Through its misted windows a man who could be Frankie can be seen at the counter eating the cafe's homemade lemon pie. Whether Frankie has in truth gone back there or not, the reprise of the shot with its suggestion of tranquillity and peace is psychologically right and complements his gracious act of compassion and kindness - it has indeed gained him a taste of heaven on earth. The implication confirms the hint given earlier when Frankie read Yeats's "The Lake Isle of Innisfree" to the hospitalised Maggie.

Frankie's enthusiasm for Irish culture is not of itself sufficient to account for the significance of his quiet but emotional reading.

I will arise and go now, and go to Innisfree,

And a small cabin build there, of clay and wattles made:

Nine bean-rows will I have there, a hive for the honey-bee,

And live alone in the bee-loud glade.

And I shall have some peace there, for peace comes dropping slow,

Dropping from the veils of the morning to where the cricket sings;

There midnight's all a glimmer, and noon a purple glow,

And evening full of the linnet's wings.

I will arise and go now, for always night and day

I hear lake water lapping with low sounds by the shore;

While I stand on the roadway, or on the pavements grey,

I hear it in the deep heart's core.

(Yeats, 1893: 12-13)

The lake isle is an image familiar to Americans: Yeats recalled that his poem owed something to Thoreau's Walden (Ibid.: 196). Both writers gave the paradise motif a post-romantic twist so that it voiced the search for peace attained through a life in which body, mind and soul harmonise with each other and the natural environment. Both encouraged meditation on the potential for deepening human experience in an enriching, quasi-religious manner through the marriage of the imagination's universe with sensory apprehension of the physical world.

The analytical psychologist C. G. Jung declared that when archetypal images surface in the psyche they compensate the dominant state of consciousness. Poetry is the arcane language of the soul. Although we have never been told why Frankie is learning the archaic language in which "The Lake Isle" was originally written, his attraction to the poetry is a part of him that connects with unconscious energies. These energies are now pushing him forward into his future. It is not too difficult to see Frankie as a man who has been standing "on the roadway, or on the pavements grey" holding an image of a paradise, than which none can be more archetypal, "in the deep heart's core". The contrast could not be more sharply drawn between the contorted life of the boxer doing everything backwards (what Scrap describes as an unnatural dream) and Yeats's vision of the soul's peace.

By the end of the film, Maggie, who has become the million dollar baby, has also achieved her dream. Dreams, whether lived out or held as an image, have significant value in opening the path toward transcendence. Dreams instil hope and are the foundation of faith in the search to find what we are missing. Joseph L. Henderson describes transcendent symbolism, which may indeed manifest in certain big dreams, as connected with periods of transition in a person's life by pointing to his or her need for liberation from a state of being that is too immature, too fixed or final. He adds that transcendent symbols concern the individual's "release from - or transcendence of - any confining pattern of existence, as he [or she] moves toward a superior or more mature stage in his [or her] development" (1964:149). It then becomes clear that the function of suffering and sacrifice in Maggie's and Frankie's lives has served its obscure purpose. 
At the end of her life, although Maggie has physically regressed into a defenceless and dependent baby, she is not an infant at all but a rich innocent in her life and psyche.

(This article is a part of a proposed book on Grieving and Cinema.)

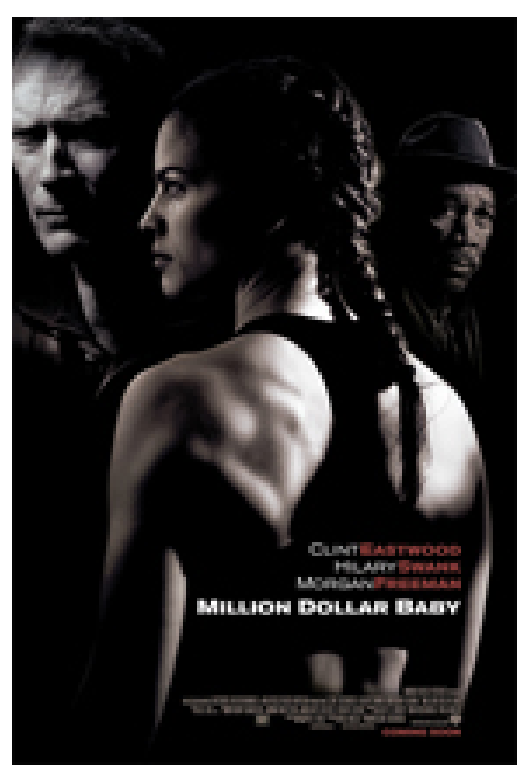

Figure 1: Million Dollar Baby (Publicity poster)

\section{References}

Buscombe, Ed (2005), "Million Dollar Baby," Sight and Sound 15, 3 (March) 67-8.

Ebert, Roger (2005), "Million Dollar Baby," Chicago Sun Times (January 7) http://www.suntimes.com/. Accessed 16 March 2005.

French, Philip (2005), "The Lord and the ring," The Observer (January 16) http://film.guardian.co.uk/News Story/Critic Review/Observer Film of the week/0,4267,1391348,00.html. Accessed 16 March 2005.

Henderson, Joseph L. (1964), "Ancient myths and modern man," in Carl G. Jung et al., Man and his Symbols. New York and London: Anchor Books, 104-57.

Humphrey, Geraldine M. and David G. Zimpfer (1996), Counselling for Grief and Bereavement. London: Sage.

Knox, Bernard M.W. (1995), "Essay: On Looking Back To Envision the Future," Cosmos http://www.cosmosclub.org/journals/1995/knox.html. Accessed 15 June 2005.

Kübler-Ross, Elisabeth (1969), On Death and Dying. London: Tavistock Publications. . (1995), Death Is of Vital Importance. Barrytown, NY: Station Hill Press.

Laplanche, J. and Pontalis, J.-B. (1973), The Language of Psycho-Analysis. New York and London: W.W. Norton \& Co.

Samuels, Andrew (ed.) (1985), The Father: Contemporary Jungian Perspectives. London: Free Association Books.

Yeats, William Butler (1893), "The Lake Isle of Innisfree," in Poems. A. Norman Jeffares (ed.). London: Macmillan [1962]. 


\section{Author Information}

John IZOD is Professor of Screen Analysis in the department of Film \& Media Studies, University of Stirling. He served as Dean of the Faculty of Arts, is a Founding Fellow of the Institute of Contemporary Scotland, and was elected a Fellow of the Royal Society for Arts in 2000. His books and articles include Reading the Screen; Hollywood and the Box Office; and The Films of Nicolas Roeg. His latest book is the Myth, Mind and the Screen: Understanding the Heroes of our Time (Cambridge, 2001). 